\title{
Bad Habits and Pernicious Results: Thumb Sucking and the Discipline of late-nineteenth-century Paediatrics
}

\author{
JONATHAN GILLIS*
}

Many are absolutely incurable and the victim may be compelled to carry the marks of this practice and their accompanying discomforts through a long life. ${ }^{1}$

So hideous is the deformity caused by this habit, that it seems incredible that it should be necessary even to call attention to it, much less to urge that action be taken to put a stop to the evil. ${ }^{2}$

Probably the most pernicious result of sucking is its tendency to develop the habit of masturbation. ${ }^{3}$

No consideration of the nervous and mental derangements of infancy would be complete which omitted the consideration of the curious group of minor psychoses which, for want of a more distinctive name, are usually referred to as "bad habits". 4

In the late nineteenth century a new subject - the infant behaviour of thumb suckingappeared on the medical stage. Thumb sucking emerged in the literature of the diseases of children in the late 1870 s and had by 1910 become a standard entry in paediatric textbooks, where it remained for the next forty years. The habit is barely mentioned in medical textbooks today, but for turn-of-the-century paediatricians it was an example of childhood pathology. It was a serious matter.

The topic has not previously received attention in the history of medicine and the only references to it appear to be scattered in commentaries on the history of child rearing. ${ }^{5}$ But, as an infant behaviour, it was evidently not a new phenomenon and in the late nineteenth century was often regarded as a source of comfort and pleasure for child and parent. When it began to be considered in medical discourse, however, it was redefined as pathology: a pathology of ugly dental malformation and worrying sexual behaviour.

\begin{abstract}
*Jonathan Gillis, MB, BS, FRACP, The Unit for the History and Philosophy of Science, University of Sydney and The Royal Alexandra Hospital for Children, Sydney, Australia. Address for correspondence: Dr Jonathan Gillis, Head, Intensive Care Unit, Royal Alexandra Hospital for Children, PO Box 3515, Parramatta, New South Wales, Australia, 2124.
\end{abstract}

I wish to thank Dr Michael Shortland of the Unit for the History and Philosophy of Science, University of Sydney, for stimulating commentary and advice; and Brenda Heagney, Librarian, History of Medicine Library, The Royal Australasian College of Physicians.

\footnotetext{
${ }^{1} \mathrm{~T}$ H Chandler, 'Thumb-sucking in childhood as a cause of subsequent irregularity of the teeth', Boston med. surg. J., 1878, 99: 204-8, p. 204.

2 Samuel Hopkins, The habit of thumb sucking, Cambridge, John Wilson, 1895, p. 7.

${ }^{3}$ Luther Emmett Holt, The diseases of infancy and childhood, New York, Appleton, 1897, p. 695.

${ }^{4}$ John Thomson, Guide to the clinical examination and treatment of sick children, 2nd ed., Edinburgh, William Green, 1908, p. 347.

${ }^{5}$ Daniel Beekman, The mechanical baby, Westport, Lawrence Hill, 1977; Martha Wolfenstein, 'Trends in infant care', Am. J Orthopsychiatry, 1953, 23:120-30.
} 


\section{Jonathan Gillis}

Paediatric textbooks came to classify the habit as a neurological disease which could only really be understood and managed by specialist paediatricians.

The argument of this paper is that the sudden medical appearance of this apparently trivial habit ${ }^{6}$ throws light on important factors involved in the establishment of the independent specialty of paediatrics, especially in the United States. I look at the treatment of the subject of infantile thumb sucking in a number of turn-of-the-century medical texts on child diseases. What emerges from this analysis is the suggestion that the transformation of a subject like thumb sucking into a defined medical condition was instrumental in helping early paediatricians justify their claim to a separate specialty.

\section{Thumb Sucking: Dental and Sexual Concerns}

Thomas Chandler, an American physician, was the first to raise medical concerns about thumb sucking. In his 1878 article in the Boston Medical and Surgical Journal, the precursor of the New England Journal of Medicine, he emphasized its dire dental consequences:

Aside from hereditary congenital deformity, which may itself have originated in this practice, there is no one cause so productive of malformations of the bones of the mouth and irregularity of the teeth as the habit of thumb sucking in infancy ... [it] disfigures the hands as well as the features, ... imparting to the whole countenance a look of idiocy ... many are absolutely incurable and the victim may be compelled to carry the marks of this practice and their accompanying discomforts through a long life. ${ }^{?}$

Although the main thrust of his argument consisted of listing the deformities of the mouth and teeth resulting from thumb sucking, Chandler's language suggested other unstated consequences. This idea was taken up by Samuel Hopkins in 1895 in a monograph on the habit where he used dental deformities as a basis to speculate on other "moral" and intellectual consequences:

There is another aspect of this question of distorted features which has not been touched upon, but which deserves serious consideration since it applies to any departure from the lines of symmetry of the body that may be brought about by ignorance or indulgence in early life. I speak now of the moral or psychical side of the question . . . children who begin life with some physical defect, be it facial deformity or a bodily ailment of any kind, are seriously handicapped in their intellectual and moral development. It would be well to remember, when indulging a child in some habit which may result in physical defect, that his moral character may also suffer from the indulgence. ${ }^{8}$

\footnotetext{
${ }^{6}$ The first mention in the medical literature appears to be Chandler, op. cit., note 1 above, in 1878. I can find no mention of thumb sucking in textbooks on children's diseases until John Keating, Cyclopaedia of the diseases of children, 5 vols, Edinburgh, Young J Pentland, 1889-1899, vol. 2, pt 2, pp. 923-4, where it is mentioned in the section on 'Diseases and care of the teeth'. Its emergence is illustrated in the writings of the British paediatrician John Thomson. He made no mention in the first edition of his textbook Guide to the clinical
}

examination and treatment of sick children, Edinburgh, William F Clay, 1898, but gave it a full entry under its own heading in the second edition in 1908 (op. cit., note 4 above). He had previously discussed the topic in an article 'On some curious habits in children', Child Study mon., 1896, 2: 88-98, but obviously did not consider it of mainstream paediatric interest until 1908.

${ }^{7}$ Chandler, op. cit., note 1 above, p. 208.

${ }^{8}$ Hopkins, op. cit., note 2 above, p. 14. 
By connecting facial deformity to negative moral development, Hopkins expanded the consequences of thumb sucking. The physical effects of a behaviour of infancy underpinned the idea of moral consequences of an indulgent habit. Such an approach would permit the idea of infant sexuality to be introduced into the discussion and would eventually consolidate the topic in the paediatric literature.

Chandler, according to the German paediatrician S Lindner writing in 1879, "is only concerned with the deformities of the teeth and does not consider the significance of thumb-sucking, etc., itself'. ${ }^{9}$ With this statement, Lindner set out to conduct the first "scientific study . . . devoted to pleasure sucking", ${ }^{10}$ in which he minutely analysed all aspects of sucking, exploring and dismissing an association with the use of pacifiers, bottle feeding, breast feeding, poverty, intelligence and spoiling. His conclusion was that "in every child there is an inherent disposition to pleasure-sucking" which is connected with the tendency of infants to put everything to their lips. He went on to describe the process of sucking: "yes, one frequently sees the pleasure sucker in his pleasure reach a state of rapture". 11 The consequences are varied: the skin of the finger or thumb is wrinkled, chewed up; the nails are cleaner and softer; intellectual deterioration; scoliosis; misshapen mouth; masturbation; a misshapen jaw and misplaced teeth. ${ }^{12}$

Lindner's observations and theories translated, in the words of later authors, into facts sometimes, but not always, accredited to him. He was referred to, in particular, by the American paediatrician Emmett Holt, who in 1897 was the first writer to include the subject as a topic in its own right in a paediatric textbook. ${ }^{13}$

Lindner introduced a sexual element to infantile thumb sucking by observing that:

All simple pleasure-suckers can increase their pleasure by active assistance: individual fingers of one or both hands rub any pleasure point on the head, neck, breast, abdomen, or pelvis. These pleasure-points [are] . . . in the pelvic area: the genitals. ${ }^{14}$

This was accompanied by an illustration of a " 6 year old thumb pleasure-sucker with active assistance, daughter of a bookkeeper"15 (Figure 1). The drawing left no doubt as to

\footnotetext{
${ }^{9} \mathrm{~S}$ Lindner, 'Das Saugen an den Fingern, Lippen, etc. bei den Kindern (Ludeln)', Jahrbuch für Kinderheilkunde (Leipzig), 1879-1880, 14: 68-91. English translation: 'The sucking of the fingers, lips etc. by children (pleasure-sucking)', Storia e Critica della Psicologia, 1980, 1: 117-43, this statement on p. 117 , fn. 2 .

${ }^{10}$ Ibid., p. 117.

${ }^{11}$ Ibid., p. 132.

12 As in all articles on this subject at that time, Lindner referred to thumb sucking as a "bad habit". The term "habit" needs exploring. What does it imply about the relation of behaviour and disease? M Bouchut in Practical treatise on the diseases of children and infants at the breast, transl. P H Bird, London, John Churchill,1855, pp. 52-4, referred to bad habits associated with crying, sleep, exercise and rest: "Nothing is more dangerous than to allow children to acquire bad habits." The word habit does not appear in medical dictionaries until the $1850 \mathrm{~s}$.
}

\footnotetext{
${ }^{13}$ Holt, op. cit., note 3 above.

14 Lindner, op. cit., note 9 above, pp. 123-4.

15 The starkness of this picture to the "modern" viewer is difficult to avoid. Although at a certain level it may be purely informative, at another there is possible evidence here for the views of Catherine MacKinnon: "In the nineteenth century men were looking at pornography, writing theology ... who is not to say they were not also looking at pornography and writing and practicing science and medicine" (Jeffrey Masson, A dark science: women, sexuality, and psychiatry in the nineteenth century, New York, Farrar,Straus \& Giroux, 1986, p. xvii). The image of the "gentlemen" discussing this picture is replete with this possibility. The implications of this for thumb sucking and paediatrics in general are complex but probably relate in general to the utility of the concept of infant sexuality. This question and whether this was a gendered utility are not the subjects of this present paper.
} 


\section{Jonathan Gillis}

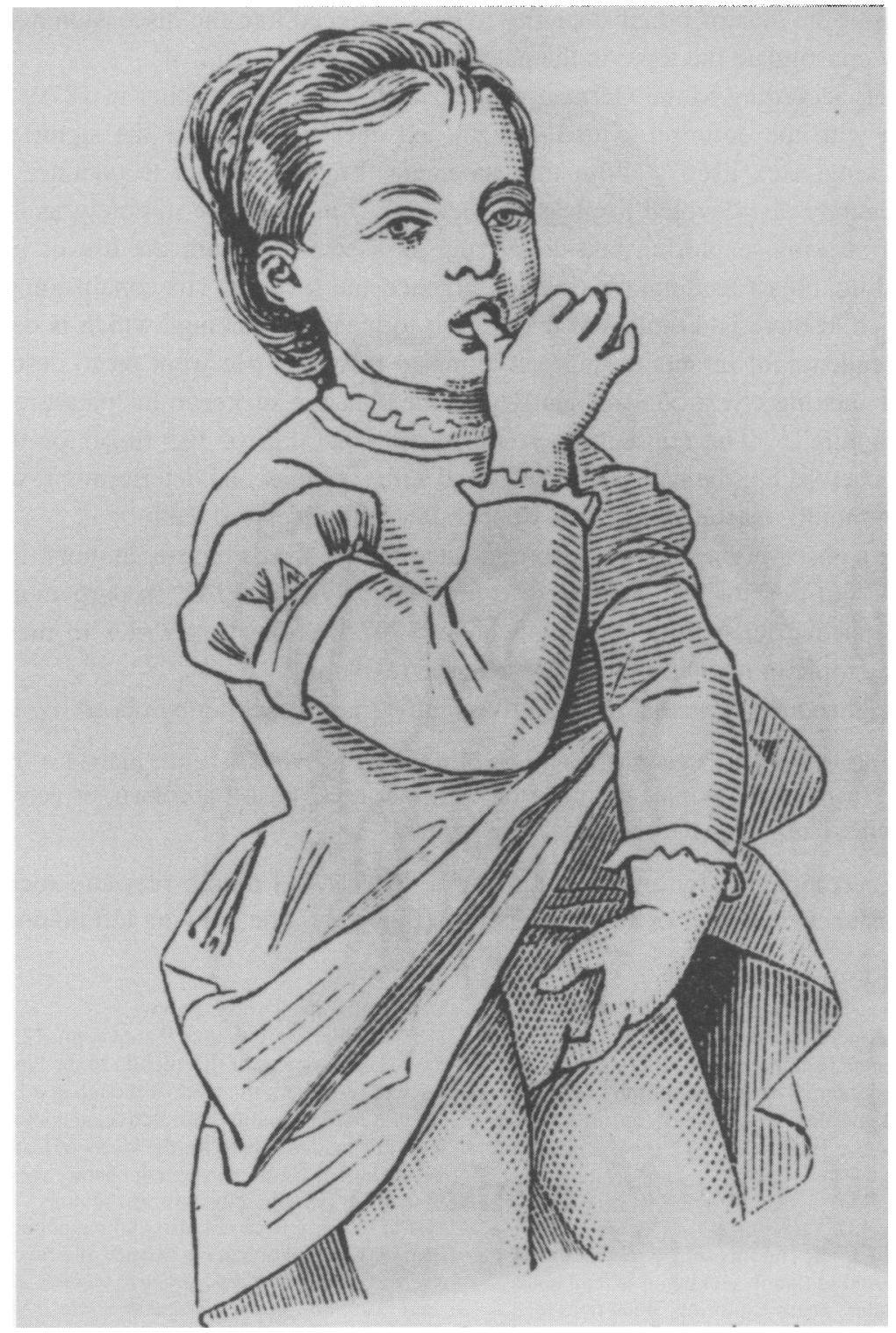

Figure 1: Six-year-old thumb pleasure-sucker with active assistance, from S Lindner, 'Das Saugen an den Fingern, Lippen, etc. bei den Kindern (Ludeln)', Jahrbuch für Kinderheilkunde (Leipzig), 1879-1880, 14: 68-61, Fig. 16, p. 74. 


\section{Thumb Sucking and the Discipline of Paediatrics}

the habit's sexual aspect and permitted a very direct reference to sexuality in a footnote to the discussion of such "active assistance":

I have no intention other than of stating a fact when I add that the pleasure of pious children are more or less the same as the highest pleasure-points in adult erotic life. The difference is that in the sexual life of adults active assistance is usually given to another heterogeneous individual, only as an exceptional deviation alone to oneself (masturbation), or to another homogenous individual (pederasty and lesbian love). Another distinction is that fondling of the pleasure-points in adult love life has rather the significance of a preparation than an accompaniment. ${ }^{16}$

The expression "pious children" was explained later: "Since children engaged in pleasure sucking when left alone are always quiet and need no rocking or singing to put them asleep mothers and nursemaids call them 'the pious ones' out of gratitude". ${ }^{17}$ But Lindner then attributed to these same children, dear to mothers and nurses, not piety, but sexuality. Such implied sexuality was confirmed for Lindner when he observed that, of the sixtynine children he studied, four sucked with "the active assistance of the genitals". The low incidence established rather than undermined the sexual interpretation:

You might want to counter here, certainly not without justification, that 4 masturbating children ... hardly permit me to count pleasure-sucking among the many causes for masturbation ... However, Gentlemen!, I would like to point out that many of my pleasure-suckers came from circles where I did not consider it socially proper to inquire or investigate more deeply. It is possible, indeed probable, that my results would have been of wider implication had there not been such obstacles. ${ }^{18}$

In this statement and in his comparison with the sexual life of adults, Lindner brought thumb sucking and masturbation within the same compass. With such a sexual focus it was the behaviour itself which commanded attention rather than its dental consequences.

The association between thumb sucking and masturbation was strengthened in paediatric literature once both behaviours were grouped under "injurious habits". This was what Emmett Holt proceeded to do in 1897 in his Diseases of infancy and childhood. After referring to Lindner, he continued: "Probably the most pernicious result of sucking is its tendency to develop the habit of masturbation". 19

Lindner's article served not only as the basis for the future paediatric discussion, but was also cited specifically by Freud in his Three essays on the theory of sexuality, ${ }^{20}$ published eight years after Holt's textbook, where he used thumb sucking as the classic example of his idea of the auto-eroticism of infancy. Holt's classification, however, was made overtly in the name of functional neurological disease rather than as forms and manifestations of infant sexuality. But this was exactly the covert message reinforced by the image of the child "indulging" pleasurably in the habit with dire consequences. The suggestive sexual warnings served to capture the topic as a concern for the paediatric specialist because the behaviour had now been endowed with a seriousness and a meaning which needed translation by experts.

${ }^{16}$ Lindner, op. cit., note 9 above, p. 127 , fn. 11 .

17 Ibid., p. 133.

18 Ibid., p. 136-7.

${ }^{19}$ Holt, op. cit., note 3 above, p. 695.

${ }^{20}$ Sigmund Freud, Three essays on the theory of

sexuality 1905 , vol. 7 in The standard edition of the complete psychological works of Sigmund Freud, ed. James Strachey, 24 vols, London, Hogarth Press, 1953-1974. 


\section{Jonathan Gillis}

The grouping of thumb sucking and masturbation had two further significant effects. Firstly, the connection with thumb sucking brought masturbation into mainstream paediatric thinking. Next, this linkage allowed a partial symbolic representation of ideas of infantile sexuality, which was non-threatening and usable in paediatrics.

Ideas of child and infantile sexuality were in circulation well before Freud ${ }^{21}$ and discussions are to be found in the psychology and psychiatry literature from 1870. In the paediatric literature any mention of infantile sexuality was by way of reports of infantile hysteria and masturbation. ${ }^{22}$ Masturbation was not mentioned at all in many of the paediatric textbooks published between 1855 and $1898 .{ }^{23}$ Eduard Henoch in his Lectures on children's diseases (1888) discussed it under 'The hysterical affections of children' and it appeared in John Keating's Cyclopaedia of the diseases of children (1890) in the chapter on 'Insanity'. ${ }^{24}$ By contrast the same textbook mentioned thumb sucking in the chapter on 'Diseases and care of the teeth'. Other textbooks did not list masturbation as a separate subject in its own right, but only as a cause of other conditions. W Day, in On the diseases of children (1885), suggested it as a cause of epilepsy and chorea, while Henry Koplick's The diseases of infancy and childhood (1906) mentioned it as a cause of hysteria. ${ }^{25}$

Paediatric texts of the period did not therefore exhibit a coherent conception of the place of masturbation in the medicine of childhood. Linkage with thumb sucking was to change this. Masturbation was now to be found under its own heading with a group of implied like conditions. Not only was there organizational grouping, but there was usually also an introductory paragraph about features the two habits had in common; the language used about thumb sucking, masturbation and other "injurious habits" became similar; and the treatment followed the same strategy, even to the extent of identical apparatus being used. Thus, in The diseases of infancy and childhood under the heading 'Injurious habits of infancy and childhood', Holt stated:

On account of the close connection of these habits with disturbances of the nervous system, they may be properly considered with the functional nervous diseases. Although some of these habits may not be of serious importance, yet as a group they have received altogether too little attention at the hands of the physician. ${ }^{26}$

In Holt's chapter there is an almost identical tone in the sections on the two habits: one of wanting the subject to be taken seriously and a sense of urgency about the treatment. An increasing identification of the two behaviours was shown by authors such as Karl Goldstone, who advised the same treatment for both masturbation and thumb sucking:

\footnotetext{
${ }^{21}$ Stephen Kern, 'Freud and the discovery of child sexuality', Hist. Childhood q., 1973, 1: 118-26.

$22 \mathrm{~K}$ Codell Carter, 'Infantile hysteria and infantile sexuality in late-nineteenth-century Germanlanguage medical literature', Med. Hist., 1983, 27: 186-96.

${ }^{23}$ For example, Bouchut, op. cit., note 12 above; $\mathrm{F}$ and $\mathrm{F}$ Churchill, The diseases of children, Dublin, Fannin, 1870; T J Graham, On the management and disorders of infancy and childhood, London, Simpkin, Marshall, 1873; Charles West, Lectures on the diseases of infancy and childhood, London, Longmans, Green, 1874; Thomas Rotch, Pediatrics:
}

the hygienic and medical treatment of children, Edinburgh, Young J Pentland, 1896; Thomson, 1898, op. cit., note 6 above.

${ }^{24}$ Eduard Henoch, Lectures on children's diseases, 4th ed., transl. John Thomson, London, New Sydenham Society, 1889; Keating, op. cit., note 6 above.

${ }^{25} \mathrm{~W}$ H Day, On the diseases of children, London, J \& A Churchill, 1885; Henry Koplick, The diseases of infancy and childhood, New York, Lea Bros., 1906.

${ }^{26}$ Holt, op. cit, note 3 above; p. 695. 


\section{Thumb Sucking and the Discipline of Paediatrics}

"early restraint, gentle admonition, and hygiene". ${ }^{27}$ More specifically Charles Kerley in The practice of pediatrics suggested: "As a means for the prevention of scratching, thumband finger-sucking, nose-boring, ear- and lip-pulling, and masturbation, the "Hand-I-Hold Mit' renders good service." 28 The accompanying illustration (Figure 2) shows how "medical" the subject had become, complete with $\mathrm{x}$-ray view of the enclosed hand.

The discussion of masturbation and thumb sucking in paediatric literature therefore converged both in language and content. The effect of this was to bring masturbation into a position where it was relevant to mainstream paediatric interests. It was now recognized as a common problem by virtue of being within a category which could be applied across the whole spectrum of infancy and childhood. In addition, the implied similarity between the two habits led covertly to the widening of the idea of infant sexuality. Indeed thumb sucking became a means to explore infant sexuality without directly confronting the subject.

\section{Behaviour and Hygiene}

Underlying the evolving discussion of thumb sucking in paediatric literature was an important dilemma which focused on the infant context of the behaviour. Since thumb sucking is uniquely a behaviour of infancy, is it really pathological? How can pathology be defined in this context? Is there a firm reference point against which to measure pathology? The difficulty of judging a behaviour in the context of infancy was resolved by interpreting it in the language of adult consequences; this was realized by constructing it in terms of prevention and prophylaxis. ${ }^{29}$ Such discussion should also be seen against a background of a wider medical interest in child behaviour and its neurological basis. Childhood was important because of the possibility of hereditary degenerative disorders. Henry Maudsley's The pathology of mind (published in 1879), for example, contained an extensive chapter on 'The insanity of early life'. 30

Holt identified thumb sucking as "a very common habit in infants, and during the first few months it is seen to some degree in most of them. If they are carefully watched the habit is easily stopped." 31 The problem was one of a very frequent behaviour being defined as pathological, of what was usual being undesirable. This led the paediatrician $\mathrm{E}$ Brush to object to the habit without having to rely on ideas of pathology:

I have not been able to convince myself that for the first year of infant life any possible harm can come from this habit. ... After the child is old enough for the habit to seem unseemly, and in older children it has a tendency to make them stupid, the habit can be cured. ${ }^{32}$

\footnotetext{
${ }^{27}$ Karl Goldstone, 'The injurious habits and practices of childhood: their detection and correction', Med. Rec., 1908, pp. 1030-3, on p. 1031.

${ }^{28}$ Charles Kerley, The practice of pediatrics, Philadelphia, W B Saunders, 1914, p. 468.

29 This preventative strategy and prophylactic programme were to become hallmarks of paediatric practice and theory.
}

\footnotetext{
${ }^{30}$ Henry Maudsley, The pathology of mind, London, Macmillan, 1879, pp. 256-95.

${ }^{31}$ Holt, op. cit., note 3 above, p. 695.

32 E F Brush, 'Infant hygiene', Archs Pediatrics, 1891, 8: 94-101, p. 98.
} 


\section{Jonathan Gillis}

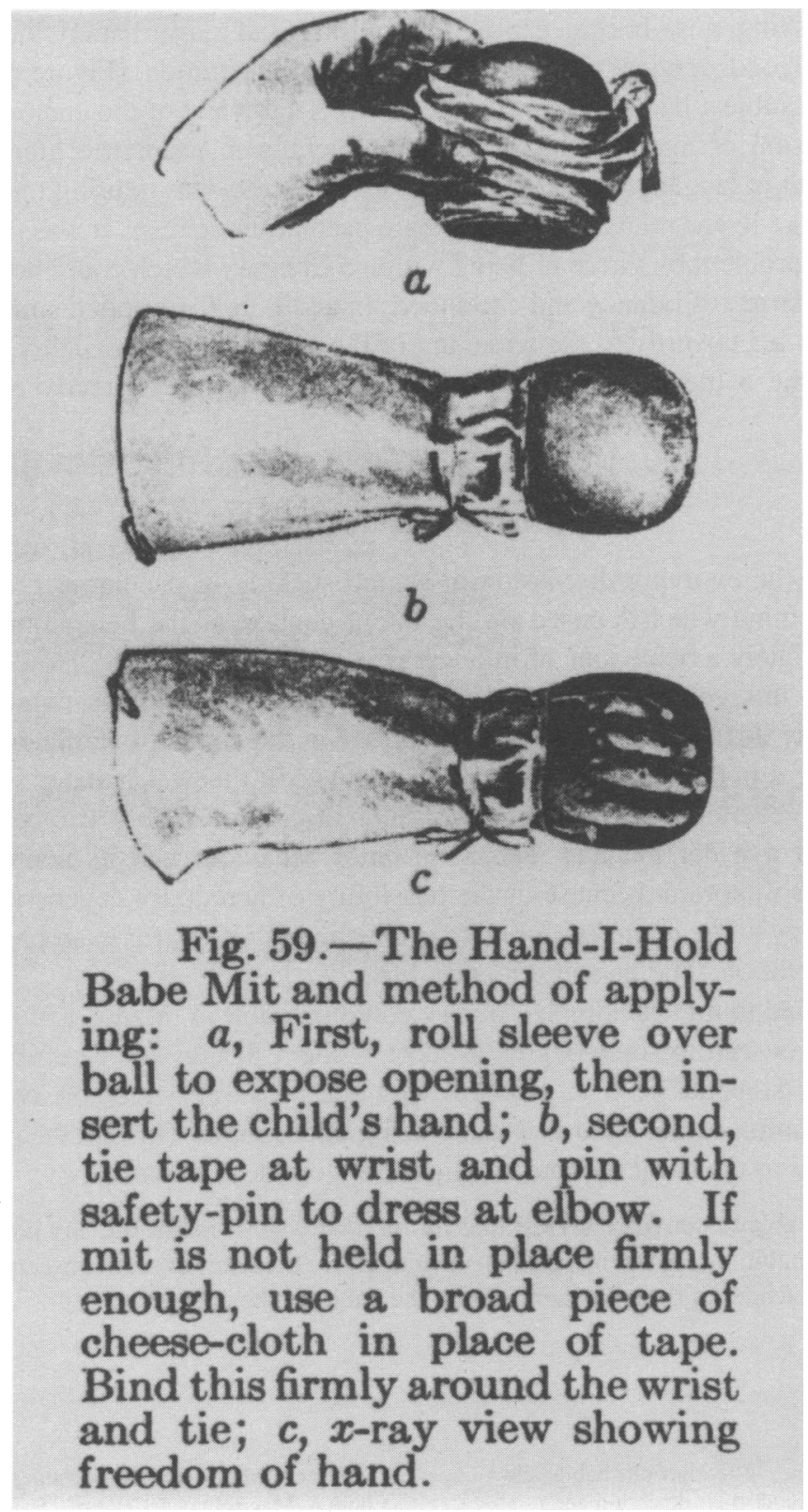

Figure 2: The Hand-I-Hold Babe Mit, from C G Kerley, The practice of pediatrics, Philadelphia, W B Saunders, 1914, p. 468. 


\section{Thumb Sucking and the Discipline of Paediatrics}

John Thomson in his article 'On some curious habits in children' referred to them as a:

little sin of commission - they consist of doing things that ought not to be done . . . They are certainly to be regarded as minor psychoses . . . There can be no doubt that in ordinarily healthy children, unless carried far or accompanied by manifestations of excitement, they often do no great harm, although certainly they are always objectionable. ${ }^{33}$

There seems to be a struggle here between an attempt to understand child behaviour within its own context and a need to define it in medical terms. Particularly revealing are almost buried remarks in some articles hinting at a positive aspect to the habit:

Only the occurrence of an acute or, under certain circumstances, a chronic illness may interrupt pleasure-sucking. The reawakening of a desire to suck for pleasure may often be taken as a prognostic sign that the child will soon recover. Never was I so glad to see my daughter suck her thumb as after she had had diphtheria, which had caused my colleagues and I to give the child up. ${ }^{34}$

Children prone to this habit are less fretful even during illness, and at all times it seems to be a source of solid comfort. ${ }^{35}$

I have, however, seen one case where a baby with very severe paroxysms of whooping-cough was more soothed by being taught to suck a "comforter" than by any sedative medicine. ${ }^{36}$

Such sentiments disappeared as the medical approach to thumb sucking asserted its authority. The attributing of positive aspects to the behaviour was to be identified as a parental phenomenon which highlighted the need for parental re-education by paediatricians. Displacement of these sentiments was achieved by linking the behaviour to adult consequences far removed from the child context. Normal child behaviour could thus be defined as pathological by redefining it in adult terms. Medicine and, in particular, paediatrics could then intervene in childhood under the banner of prophylaxis or as Goldstone (1908) phrased it: "two of the heaviest spokes in the wheel of medical septuary namely, Etiology and Prophylaxis."37

An example of this reworking of a normal childhood behaviour into a pathological behaviour because of its adult consequences is to be found in Benjamin Rachford's book Neurotic disorders of childhood (1905):

Thumb sucking is a habit neurosis which has its origin in the animal instinct of self-preservation, which causes the infant to suck everything that comes into contact with its lips. The child by instinct conveys to its mouth everything that touches its hands, and when nothing happens to be in the hand the child places its thumb, finger or some other portion of its body in its mouth. ... The habit of sucking does not produce any notable constitutional disturbances . . . [it] does produce certain deformities . . . it is therefore for the purpose of preventing these deformities that the sucking habit should be prevented. ${ }^{38}$

\footnotetext{
33 Thomson, op. cit., note 6 above, p. 88.

${ }^{34}$ Lindner, op. cit., note 9 above, p. 133.

35 Brush, op. cit., note 32 above, p. 98.

36 Thomson, op. cit., note 4 above, p. 351 .

37 Goldstone, op. cit., note 27 above, p. 1030.

38 Benjamin Rachford, Neurotic disorders of childhood, New York, E B Treat, 1905, pp. 407-8. It is of interest to compare the medical approach of highlighting negative adult consequences with the anthropological and sociological analysis of child behaviour. E C Sanford, 'Mental growth and decay', Am. J. Psychol., 1902, 13: 426-49 emphasized a
}

developmental approach: "Anything brought to the mouth is sucked and mumbled with the greatest enjoyment ... it is probably the fact that what they are really enjoying are the muscular pleasures of sucking and the tactile pleasures of feeling of objects with the lips and tongue ... When the hands come into the mouth in the way just described they also are sucked and mumbled like other things, and perhaps give rise to an especial pleasure because of the double touch sensations-in both mouth and handthat are then experienced. . . . By the middle of the third month, perhaps, the baby has mastered the 


\section{Jonathan Gillis}

The dental consequences of thumb sucking would provide the somatic evidence of the behaviour's pathology. The association with masturbation, initially tentatively suggested by Lindner, now became fact: "Infants who persist in the habit of sucking always become masturbators".39

The behaviour was therefore now judged in terms of its consequences: "The results of sucking may be serious"; 40 "in pointing out the evils that arise from the infantile habit of sucking the thumb, finger, or other object, it is hoped that a note of warning may be sounded". 41 Such a definition of pathology naturally led to a treatment strategy of prevention. Hopkins' "note of warning" in his monograph The habit of thumb sucking led him into a dramatic description of this strategy: "In much the same way, a surgeon would cheerfully prevent a surgical operation by rescuing a man from his dangerous position in front of an approaching locomotive". 42 Or as more clearly stated by C G Kerley in his 1914 textbook: "As our sole object is the production of a normal adult, only those habits tending toward proper growth and development should be encouraged". 43

Paediatrics therefore deals with a different world to the rest of medicine with different reference points. Thomas Rotch in his presidential address of 1891 to the American Pediatric Society explained to his fellow paediatricians:

We have entered upon the especial investigation and research in this branch of anthropology with the keen interest of explorers in an almost unknown country. Of still further interest, also, when we discover not only that there is a vast expanse of unknown, but that much which was supposed to be known is in reality a poor subterfuge of unreal facts forming structures of misleading results, which in the scientific medicine of adults would not for a second be tolerated. ${ }^{44}$

Paediatrics is therefore an early intellectual example of contextual or relative "truth". The initial difficulty in interpreting thumb sucking represents a struggle with this concept. The solution imposed reinforces an absolute standard by anchoring the behaviour in its adult consequences.

\section{A Place within Paediatric Neurology}

In his 1897 textbook Holt was the first to place thumb sucking in a section on 'Diseases of the nervous system', where he discussed it under the heading 'Injurious habits of infancy and childhood': "On account of the close connection of these habits with

movement and specialized upon the thumbs as the most convenient part of the hand for sucking." This appears to be an attempt to understand the behaviour on its own terms. Similarly S Buckman in an article entitled 'Babies and monkeys' (Ninet. Century, 1894, 36: 727-43), saw it in terms of recapitulation theory or, like Chamberlain in 1900 , in terms of the child as a revealer of past atavisms. "Sucking, of course, is an act of childhood-it is one of the most important incidents connected therewith. The baby sucks to satisfy hunger; and associated with sucking are the feelings of warmth, sleep and comfort ... it has developed into sucking to alleviate any distress or pain generally. Thus when an infant is hurt ... it forgets its trouble in sucking. All these associations are potent in later life." (Buckman.) In this analysis the behaviour is neither abnormal in childhood or in its adult consequence. The behaviour in fact is of phylogenetic significance. "Treatment" is not a concept here. A F Chamberlain, The child: a study in the evolution of man, London, Walter Scott, 1900.

${ }^{39}$ Goldstone, op. cit., note 27 above, p. 1031.

${ }^{40}$ Holt, op. cit., note 3 above, p. 695.

${ }^{41}$ Hopkins, op. cit., note 2 above, pp. $3-4$.

42 Ibid., p. 4.

${ }^{43}$ Kerley, op. cit., note 28 above, p. 463.

44 Thomas Rotch, 'Iconoclasm and original thought in the study of pediatrics', Archs Pediatrics, 1891, 7: 806-11, p. 806. 


\section{Thumb Sucking and the Discipline of Paediatrics}

disturbances of the nervous system, they may be properly considered with the functional nervous diseases". ${ }^{45}$ Sucking still caused the same things including jaw and dental deformities, masturbation and scoliosis. But it had now been categorized with the other "injurious habits" of masturbation, tongue sucking and nail biting.

There was no attempt to justify further the neurological classification of thumb sucking. Holt's general view of the "peculiarities in the diseases of the nervous system in infancy and childhood", however, gives some clues:

At this time, apparently trivial causes are enough to produce quite profound nervous impressions, because of the instability of the nervous centres and the greater irritability of the motor, sensory, and vaso-motor nerves. These are conditions which are very much increased by all disturbances of nutrition. These disturbances may be manifold in character, but they lie at the root of very many of the neuroses of early life,-e.g., extreme nervousness, disorders of sleep, stuttering, chorea, incontinence of urine, tetany and convulsions.... it follows that the hygiene of the nervous system is of the utmost importance in infancy and childhood. ... A normal development can take place only in the midst of quiet and peaceful surroundings, with plenty of time for rest and sleep. The conditions of modern life, especially in cities, are such that these laws are almost invariably violated, and the consequences of this are seen in the marked and steady increase in nervous diseases among children. ${ }^{46}$

Holt here focused on infant behaviours as possible manifestations of neurological pathology with an emphasis on prophylaxis and hygiene of the nervous system for normal development. In his discussion, Holt referred to Rachford, who, in Neurotic disorders of childhood, placed thumb sucking under the "neuroses of childhood" which he defined as. "nervous disorders which do not depend on known local pathological lesions of the nervous system":

This definition of the term neuroses does not imply that these diseases have an entirely unknown pathology, but they cannot be morphologically classified. In these diseases we know more of the symptoms than we do of the lesions, more of the effect than we do of the cause, more of the disordered functions of the nerve cells than we do of the widely pathological conditions which produce these disordered functions. ${ }^{47}$

The discussion of habits in general, and thumb sucking in particular, therefore found a pathological anchor in "functional neurological disease". This was a natural outcome of the sequence described in the previous section. Normal infant behaviour was reworked into a pathological behaviour by way of its adult consequences. Once the behaviour was defined in pathological terms the focus shifted back from the consequences to the behaviour itself. Thumb sucking had now to be placed in the medical schema and given a nosological anchor. "Functional neurological disease" or "neurosis" was a useful category with no very clear definition.

The discussion of thumb sucking in paediatric textbooks was consolidated after Holt, appearing in the sections on neurological disease and usually under the functional or neurosis category. ${ }^{48}$ Initially, at least, such a classification would appear to be a

45 Holt, op. cit., note 3 above, p. 695.

46 Ibid., pp. 652-3.

47 Rachford, op. cit., note 38 above, p. 13.

${ }^{48}$ For example A Jacobi (ed.), Modern clinical medicine diseases of children, New York, Appleton, 1910; Kerley, op. cit., note 28 above; Isaac Abt (ed.), Pediatrics, 9 vols, Philadelphia, W B Saunders, 1925, vol. 7. 


\section{Jonathan Gillis}

phenomenon of paediatric textbooks. A review of neurology texts at the time shows that most have no references to childhood habits or thumb sucking. ${ }^{49}$ Certainly "functional nervous disorder" is discussed at length:

... termed functional. It seems to me a vain dispute, whether in strict accuracy there are, or are not, any such disorders. The probability is there are not-that in all morbid action the cells and the fibres of the organs undergo some molecular change from their perfectly normal condition. It is, however, perfectly certain that there are very grave disorders in which the most careful scrutiny fails to detect any actual change, in which complete recovery is perfectly possible, and in which the "juvantia" are such as operate more in modifying the power of the organs than their texture. ${ }^{50}$

But, despite the availability of the classification, it is apparent that for neurology at least thumb sucking wạs not a pathology. Indeed one author on the first page of his book put the habit in its non-pathological place by referring to a situation "when a temperature of 104 degrees filled us with alarm, although the child might be placidly sucking its thumb at the time". 51

\section{Present Pleasure, Future Pathology}

Two aspects of thumb sucking were insistently emphasized throughout the emerging paediatric discussion: the pleasure the child derived from it, and the laxity shown towards it by parents, nurses and other physicians, who either treated the habit without due seriousness or wilfully encouraged it. The guardians of the child could not be the best judges of their children since they could not unaided recognize that in childhood pleasure there lurked adult pathology. As for nurses and non-paediatric physicians they often conspired unawares with parents, cementing the future debility of those in their care through their ignorance of cause and effect.

Indeed as Chandler wrote of mothers: "Even when warned and fully understanding the dangers, they in mistaken kindness, for temporary present good, neglect to provide against certain future evil." As for physicians "they have been known to advise mothers to encourage these habits, and when shown models of mouths made monstrous in this seemingly harmless manner can hardly bring themselves to believe that the special case called to their attention is anything more than an exceptional one, instead of being the type of a class." 52

The paediatric discussion of thumb sucking therefore set up a clear and consistent difference in attitude between, on the one hand the paediatric author, and on the other parents, nurses and other physicians. The observation that the behaviour was pleasurable to the infant reinforced the possibility of incorrect management by these non-paediatric groups, and by successfully deceiving them it invalidated any authority they might have claimed. The development of this paediatric stance is shown in the following passages:

\footnotetext{
${ }^{49}$ For example: C Handfield Jones, Clinical observations on functional nervous disorders, Philadelphia, Henry C Lea, 1867; L A Putzel, Treatise on common forms of functional nervous diseases, New York, William Wood, 1880; J Taylor, Paralysis and other diseases of the nervous system in childhood and early life, London, J \& A Churchill,1905; B A Sachs, Treatise on the nervous diseases of children, New York, William Wood,
}

1895; M A Starr, Organic and functional nervous diseases, 2nd ed., New York, Lea Bros, 1907; T S Clouston, The neuroses of development, Edinburgh, Oliver and Boyd, 1891.

${ }^{50}$ Handfield Jones, op. cit., note 49 above, p. 18.

${ }^{51} \mathrm{~L}$ G Guthrie, Functional nervous disorders in childhood, London, Henry Frowde, Oxford University Press, 1907.

52 Chandler, op. cit., note 1 above, p. 207. 


\section{Thumb Sucking and the Discipline of Paediatrics}

Since children engaged in pleasure sucking, when left alone, are always quiet and need no rocking or singing to put them asleep mothers and nursemaids call them the "pious ones" out of gratitude. (Lindner, 1879) $)^{53}$

It may be that there are mothers in the world who are so weak and indulgent that they cannot break up a harmful practice lest the dear child be caused some present discomfort; but it is fortunate for the future of the race that such women are in the minority. (Hopkins, 1895) $)^{54}$

Too often the habit of thumb-sucking, or of sucking a rubber nipple, is encouraged by mothers and nurses, because of the temporary quiet which is thereby produced; even physicians are sometimes accessory to this procedure. (Holt, 1897) ${ }^{55}$

The infant is allowed to form this habit because the mother or physician does not believe that it is worth while to try to prevent the formation of a habit which gives the child a pleasurable occupation and does not seriously interfere with its development. (Rachford, 1905) ${ }^{56}$

The degree to which it gains a hold over children very largely depends on the passive, if not active, encouragement it receives from the nurse or mother. The nurse finds that to check the habit means provoking no end of restlessness, screaming, and ill-temper; while, on the other hand, to encourage it is a very easy and almost infallible way of making the child quiet and easily managed-“good" she calls it. (Thomson, 1908) ( $^{57}$

Mothers will sometimes tell us with considerable amusement that the application of the bitter drug to the finger makes no difference to the child. (Kerley, 1914) ${ }^{58}$

Such statements show a hardening of attitude to mothers: observation of their probably innocent gratitude (Lindner); berated for weakness (Hopkins); selfish ignorance (Holt); uninformed ignorance (Rachford); wilful, selfish ignorance (Thomson); subversive wilfulness (Kerley). There is a hint of sarcastic hostility in the latter two statements, which possibly reflects the growing confidence of paediatrics in its authority.

Thumb sucking is therefore defined as a pathology which can be identified only by paediatricians. Such a role positions paediatrics as the vehicle of privileged knowledge about infancy and effectively excludes other competing authorities.

\section{Consolidation in the Paediatric Literature}

From the preceding discussion it would appear that thumb sucking entered mainstream paediatric discourse following an identifiable process:

(1) Dental deformities and disfigurement attributed to the infant behaviour of thumb sucking gave an opening for paediatric interest and served as a foundation for all subsequent discussions. In addition the emphasis on distorted features and ugliness provided a language and somatic representation which were used to widen the

\footnotetext{
${ }^{53}$ Lindner, op. cit., note 9 above, p. 133. It will be remembered that Lindner himself was glad when his own daughter sucked her thumb when recovering from diphtheria. This approach will be defined by paediatrics as typical parental behaviour and interestingly Lindner quarantines his own "parental" attitude in his article.
}

\footnotetext{
${ }^{54}$ Hopkins, op. cit., note 2 above, p. 15.

55 Holt, op. cit., note 3 above, pp. 695-6.

56 Rachford, op. cit., note 38 above, pp. 407-8.

57 Thomson, op. cit., note 4 above, pp. 350-1.

58 Kerley, op. cit., note 28 above, p. 464.
} 


\section{Jonathan Gillis}

consequences of the behaviour to embrace moral and intellectual functioning. ${ }^{59}$ This then enabled the subject to take on a greater paediatric significance.

(2) Masturbation, which had initially been loosely associated with the habit, was soon reported to be one of the definite consequences. This shifted the focus on thumb sucking, which now came to be seen as intrinsically sexual.

(3) The nature of the behaviour itself, therefore, became the centre of the discussion. How could it be understood in the context of infancy? Was it pathological and therefore a legitimate concern of paediatrics? The issue was resolved by interpreting thumb sucking in the language of adult consequences.

(4) A common activity of infancy was defined as pathological because of the resulting deformity and implied sexual content. The complete medical construct required a nosological anchor and a treatment strategy. These were easily provided in paediatric discourse: firstly, by the category of functional neurological disease (a classification which required no anatomical correlate); and, secondly, by programmes of prophylaxis and infant hygiene. Classification also encouraged easy transfer from textbook to textbook, ensuring its continuation as a seemingly constant body of facts designated as paediatric.

(5) Parents, nurses and other physicians could not and did not understand the pathological significance of this behaviour, especially because thumb sucking was pleasurable (or at least appeared so) for the infant. Mothers therefore could not trust their own intuition about what constituted their child's welfare. Physicians often conspired with the parents even when shown scientific evidence. Nurses encouraged the habit because of a selfish need to quieten the child. Paediatrics, therefore, became the only legitimate authority in this area.

Holt's 1897 textbook of paediatrics represents the arrival of thumb sucking as a mainstream paediatric subject. Holt's particular contribution appears to have been to isolate "injurious habits" as a group under functional neurological disease; and then to bring together thumb sucking and masturbation. Abraham Jacobi's textbook of 1910, Modern clinical medicine, diseases of children, continued this classification, ${ }^{60}$ which became standard in paediatric textbooks for the next forty years. ${ }^{61}$

Holt's inclusion of thumb sucking was therefore accepted in the paediatric agenda. (1) Why was this view successful? (2) Why was the subject not included in other paediatric textbooks of the time?

The influence of Holt's view was based to a degree on his personal involvement and status in early paediatric education. The subject became popular with him and a common

\footnotetext{
${ }^{59}$ For example: "imparting to the whole countenance a look of idiocy . . . the victim may be compelled to carry the marks of this practice and their accompanying discomforts through a long life" (Chandler, op. cit., note 1 above); "the individual beauty of the face suffers conspicuously" (Lindner, op. cit., note 9 above); "so hideous is the deformity ... put a stop to the evil" (Hopkins, op. cit., note 2 above.)
}

\footnotetext{
60 Jacobi, op. cit, note 48 above.

${ }^{61}$ For example: Kerley, 1914, op. cit. note 28 above; Abt, 1925, op. cit., note 48 above; D Paterson, Sick children: diagnosis and treatment, London, Cassell, 1930; W C Davison, The compleat pediatrician, 2nd ed., Durham, Duke University Press, 1938; W Nelson (ed.), Mitchell-Nelson textbook of pediatrics, Philadelphia, W B Saunders, 1946.
} 
topic in his medical teaching. ${ }^{62}$ In his position as Physician-in-charge at the Babies Hospital of New York, and Professor of Paediatrics at the New York College of Physicians and Surgeons, Holt educated and trained many future influential American paediatricians. ${ }^{63}$ This served to establish thumb sucking and similar topics within paediatric discourse by passing them on to the next generation of paediatricians. It was also helped by the remarkable success of his textbook (3rd edition 1907, 6th edition 1911, 9th edition 1926).

The acceptance of Holt's approach resulted from more than practical circumstances. It was also connected to a particular definition of paediatric discourse. ${ }^{64}$ Comparisons between Holt's textbook and those of other paediatricians give an idea of what thumb sucking represented or carried with it in theoretical terms. Thomas Rotch's Pediatrics: the hygienic and medical treatment of children, published in 1896, one year before Holt's book, is a useful example. ${ }^{65}$ Thumb sucking was not mentioned in it despite a long section on "functional nervous diseases". Rotch, like Holt, was an important and influential paediatrician, holding the first chair in paediatrics at Harvard. ${ }^{66}$

Rotch's view of paediatrics emphasized the normal child. His textbook begins:

We are to-day beginning the study of a branch of medicine which will be of the greatest practical importance to you in your future careers . . . The difficulties to be surmounted in correctly diagnosticating and treating young children are far greater than those which you encounter in adult life. The reason for this is that for adult cases you have some standard by which you can be guided, being yourselves adults. What standard, however, have you for the feelings and sensitive organization of the child? None within yourselves; it must all come from long and patient observation, with its resulting experience ... In studying, then, the different stages of development in children, we are in reality acquiring a new alphabet, which when once thoroughly mastered will enable us to read the otherwise obscure language presented to us for translation by the various diseases of early life. The proper method of learning to understand sick infants and children is first to notice their peculiarities in health. ${ }^{67}$

Rotch's lack of an easy "standard" made him tentative in defining abnormality and led to his placing less emphasis on hygiene and prophylaxis. This approach made it more difficult for him to define rigidly a paediatrics with special medical utility beyond general medicine.

Compare this approach to the opening lines of Emmett Holt's The diseases of infancy and childhood:

\footnotetext{
62 See R L Duffus and L E Holt, jnr, L. Emmett Holt: pioneer of a children's century, New York, Appleton-Century, 1940. In the Foreword, the distinguished paediatrician E A Park comments: "In his teaching Dr Holt chose the common conditions and diseases ... I recall interesting hours devoted to the small humdrums of paediatric practice-thumb sucking, habit spasm, bed wetting, diaper eruptions and so on."

${ }^{63}$ B S Veeder, Pediatric profiles, St Louis, C V Mosby, 1957, pp. 33-60, "American pediatrics is Holt's monument” (p. 60).
}

\footnotetext{
64 Of interest here is a comment in the review of Holt's textbook in Archives of Pediatrics, 1897, 14: 937-45. "In studying the book one is impressed with the fact that the author has written with full appreciation of the peculiar position occupied by pediatrics as a department of medicine" (p. 944).

65 Rotch, op. cit., note 23 above.

66 Both Holt and Rotch are discussed in AbtGarrison, History of pediatrics, Philadelphia, W B Saunders, 1965, pp. 141-2; and in Veeder, op. cit., note 63 above: Holt, pp. 33-60, Rotch, pp. 29-32.

${ }^{67}$ Rotch, op. cit., note 23 above, pp. 17-18.
} 


\section{Jonathan Gillis}

The physical development of the child is essentially the product of the three factors-inheritance, surroundings, and food. The first of these it is beyond the physician's power to alter; the second is largely and the third almost entirely within his control, at least in the more intelligent classes of society. These two subjects, infant hygiene and infant feeding, are the most important departments of pediatrics. ${ }^{68}$

Holt had a much more certain conception of paediatrics with a clear focus on pathology and a clear strategy of infant hygiene and prophylaxis. There was little attention given to the normal anthropology or alphabet of the child world. That world was clearly understood in adult terms. Paediatrics had a special utility in its emphasis on "training in proper habits" and hygiene especially in regard to "functional nervous diseases":

Great injury is done to the nervous system of children by the influences with which they are surrounded during infancy, especially during the first year. . . The steadily increasing frequency of functional nervous diseases among young children is one of the most powerful arguments for greater attention by physicians to the subject of the hygiene of the nervous system during infancy. ${ }^{69}$

There is no more promising field in medicine than the prevention of disease in childhood. The majority of the ailments from which children die, it is within the power of man in great measure to prevent. Prophylaxis should aim at the solution of two distinct problems: (1) The removal of causes which interfere with the proper growth and development of children; (2) the prevention of infection. The former can only come through the education first of the profession and then the general public, in the fundamental principles of infant feeding and hygiene. ${ }^{70}$

Holt's approach therefore could logically include thumb sucking in the domain of paediatrics. It fitted easily into his focus on hygiene, prophylaxis and functional neurological disease. As pathology it both represented and defined a paediatric discourse. By taking a simple infant behaviour as pathology Holt took paediatric discourse into the essence of infancy. Rotch's paediatric construct, on the other hand, could not find room for this new pathology. As a result it left a vast area of infant life closed to medical restructuring and weakened the power of paediatric discourse.

This interpretation is confirmed by looking at statements by early paediatricians in support of a separate specialty of paediatrics, especially in the form that it took in the United States. ${ }^{71}$ Their two main dilemmas were that, firstly, paediatrics was not an organ based specialty like, for example, ophthalmology and, secondly, the management of children's diseases had always been practised by other general physicians. As a result paediatrics had difficulty in demarcating itself from general medicine. ${ }^{72}$ In response to this

${ }^{68}$ Holt, op. cit., note 3 above, p. 1 .

69 Ibid., p. 5.

70 Ibid., p. 44

${ }^{71}$ In Britain paediatrics developed as a consultative rather than a primary care specialty. I have not explored here whether the treatment of subjects like thumb sucking had different implications for the emergence of paediatrics in different countries. I have referred to both British and American texts, but have not followed the European path beyond Lindner.

72 A number of factors leading to the inception of the specialty of paediatrics in the United States in the late nineteenth century have been identified by Sydney Halpern, American pediatrics, Berkeley, University of
California Press, 1988, p. 55. These include "social meliorism directed toward children of the poor, the founding of children's hospitals and asylums, and the emergence of new work patterns among a segment of elite physicians. Children's institutions provided the basis for semi-specialized medical careers which, in turn, stimulated the consolidation of pediatrics as a medical segment." She goes on to include "the impact of recently founded specialty societies" and the relevance of recent scientific discoveries to paediatrics. These factors help to explain why a number of physicians came to attempt to create the specialty of paediatrics, but this attempt needed justification at an intellectual level. 


\section{Thumb Sucking and the Discipline of Paediatrics}

difficulty two major justifications for a separate specialty were developed: children and their diseases exist in a different world that needs a different approach and understanding; children and their diseases are critical for the development of future adults and in turn society and therefore need particular concentration of expertise.

The first justification was portrayed by Thomas Rotch in his 1891 presidential address to the American Pediatric Society: "We have entered upon the especial investigation of and research in this branch of anthropology with the keen interests of explorers in an almost unknown country". ${ }^{73}$ This country had been poorly explored by others:

As I look upon the members of our Pediatric Society and see how well fitted they are to be leaders in the several communities wherein their lot is cast, it is impressed upon me that . . our Society should represent advanced and general ideas ... Thus only can the unenlightened influence of the profession at large on the laity be curbed in the harm it is continually doing to scientific medicine; thus only can the self-sufficient ignorance regarding the most critical period of human existence be properly combated, and the general physician be forced to understand that he has but a limited knowledge of what he has been in the habit of considering simple questions ... men who have done much for humanity in other branches of medicine, and yet who, with dignified authority, continue to utter dead platitudes concerning children. ${ }^{74}$

In this way the separate domain of paediatrics was staked out from the rest of medicine. The Paris paediatrician, Grancher, set out its authority very clearly by defining paediatrics as the study and practice of a special knowledge not accessible to mothers, other physicians, and nurses:

But with the infant the doctor needs special means, as he has not only to make a correct diagnosis, but he must meet the constant agitation of the child itself, and the stupidity of the nurse, with the weakness, not to say cowardice of the mother. ${ }^{75}$

The second justification for paediatrics was established by relating infancy to future adulthood. Such a connection was provided by the concept of development, which would in turn introduce ideas of hygiene and prevention. Christopher in his 1902 presidential address to the American Pediatric Society spelt this out:

I am firmly convinced that no other department of medicine has to do with more fundamental biologic truths ... The one feature which categorizes pediatrics and its framework is development ... It aims to so control the environment of the developing individual . . . in other words, it aims to make of the child the strongest possible adult. Pediatrics, therefore, is preventative medicine of the highest order, and is only possible because of the existence of the developmental period of human life, and because this development can be acted upon, and acted upon strongly, by environment, and either advantageously or disadvantageously. ${ }^{76}$

The theme was repeated by many authors of the time as they defined the specialty of paediatrics. An 1897 editorial in the Archives of Pediatrics entitled 'Is pediatrics a specialty?' stated:

${ }^{73}$ Rotch, op. cit., note 44 above, p. 806 . The explorer metaphor is a recurring one at that time: Grancher 1890 quoted in 'Letter from Paris', Archs Pediatrics, 1890, 7: 763-4: "Professor Grancher, who holds the official chair of children's diseases in the Paris Faculty of Medicine, lately gave an interesting lecture on this subject. He said that West,
Roger, and Valleix held that 'children's diseases were like a new country, where the explorer heard a language unknown to him"'.

${ }_{74}$ Rotch, op. cit., note 44 above, p. 808 .

75 Grancher, op. cit., note 73 above, p. 764.

76 W S Christopher, 'Development, the keynote of pediatrics', Archs Pediatrics, 1902, 19: 481-2. 


\section{Jonathan Gillis}

Pediatrics is, however, as properly a specialty as is ophthalmology. Man, the highest animal of creation, starts in life the most imperfectly developed and the most helpless of all. The formative and developmental period, therefore, is in many regards the most important one of his life. Hence, the proper management of infant man in health and the treatment of the many diseases peculiar to his growth and development form a specialty of very great importance. ${ }^{77}$

If development is the territory of paediatrics, the problem of not being a single organ specialty is solved. Abraham Jacobi, the first professor of diseases of children in America, could therefore, in his 1889 presidential address to the American Pediatric Society, claim for paediatrics:

the entire organism at the very period which presents the most interesting features to the student of biology and medicine. Infancy and childhood are the links between conception and death, between the foetus and the adult. ${ }^{78}$

This emphasis on development naturally led to the adult consequences of childhood and the strategies of hygiene and prophylaxis. For Holt this was central to his notion of paediatrics:

Infant hygiene and infant feeding are the two most important departments of pediatrics ...

Conditions interfering with proper growth and development-These are among the largest etiological factors in the diseases of infancy. They are improper food or feeding, unhygienic surroundings, and neglect. . . . they become most important predisposing factors . . . later in childhood, to functional nervous diseases. ${ }^{79}$

For Jacobi this stategy would give paediatrics a central role in society, further justifying its importance as a separate discipline of medicine:

Pedology is the science of the young. The young are the future makers and owners of the world. Their physical and moral condition will decide whether the globe will be more Cossack or more republican, more criminal or more righteous. For their education and training and capabilities, the physician, mainly the pediatrist, as the representative of medical science and art, should become responsible. $^{80}$

Hence paediatrics had an early emphasis on health rather than disease and prevention rather than treatment. By 1923 a leading paediatrician could say:

Child hygiene is at present the most important motif in our work ... it has been the child that has been the topic of consideration-not disease or medicine. ...

... we are interested in the knowledge of normal growth and development of the child and in methods of preventing disease and deviations from normal development. ${ }^{81}$

The emerging paediatric discourse therefore included ideas of the unique world of the healthy infant and child requiring special expertise to interpret pathology; the exclusion of

${ }^{77}$ Editorial, Archs Pediatrics, 1897, 14: 51.

78 Abraham Jacobi, 'The relations of pediatrics to general medicine', Archs Pediatrics, 1889, 16: 760.

${ }^{79}$ Holt, op. cit., note 3 above, pp. 1, 30-1.

${ }^{80}$ Abraham Jacobi, 'The history of pediatrics and its relation to other sciences and arts', Archs Pediatrics, 1904, 21: 833.
${ }^{81}$ B S Veeder, 'Pediatrics and the child', J. Am. med. Ass., 1923, 81: 4518; and idem, Preventive pediatrics, New York, Appleton, 1926, p. 169, both quoted in Halpern, op. cit., note 72 above, p. $96,97$. 
other possible authorities; development as a critical time in the life of the human being; the consequences of abnormal development for adulthood and therefore the race; prevention as a therapeutic strategy.

Each of these elements has been shown here to be integral to the evolution of thumb sucking as a medical topic. Essential to such a definition of the paediatric agenda was an expansion of its domain beyond specific diseases to aspects of normal and abnormal development. Thumb sucking is located in this domain. It was a sentinel topic in that it was the type of subject that paediatrics needed to rework to achieve a role beyond specific disease states. Its special utility for this paediatric discourse lay in its frequency, the fact that parents sought medical advice about it, ${ }^{82}$ and the fertile ground of uncertainty as to whether it was pathological. At the same time the processes involved in the reworking of thumb sucking into paediatric pathology were fundamental to the strategy by which paediatrics attempted to become the sole authority with privileged knowledge on children in general. The claims of paediatrics were then reinforced by subjects like thumb sucking acting as vehicles for other knowledge of the child to enter and then constitute the paediatric discourse. Thomas Rotch had seen himself as an "explorer in an almost unknown country", but thumb sucking would help establish paediatrics as the colonizer in the land of infancy.

82 Brush, op. cit., note 32 above, p. 98. 